\title{
Intermédialités
}

Histoire et théorie des arts, des lettres et des techniques

Intermediality

History and Theory of the Arts, Literature and Technologies

\section{Letters On The Move: Erín Moure and Chus Pato's Secession/Insecession and Nathanaël (Nathalie Stephens)'s Absence Where As (Claude Cahun and the Unopened Book)}

\section{Geneviève Robichaud}

Numéro 27, printemps 2016

traduire

translating

URI : https://id.erudit.org/iderudit/1039815ar

DOI : https://doi.org/10.7202/1039815ar

Aller au sommaire du numéro

Éditeur(s)

Revue intermédialités (Presses de l’Université de Montréal)

ISSN

1920-3136 (numérique)

Découvrir la revue

Citer cet article

Robichaud, G. (2016). Letters On The Move: Erín Moure and Chus Pato's Secession/Insecession and Nathanaël (Nathalie Stephens)'s Absence Where As (Claude Cahun and the Unopened Book). Intermédialités / Intermediality, (27). https://doi.org/10.7202/1039815ar
Résumé de l'article

Dans ce texte, je me propose d'étudier l'espace d'échange et de dialogue déployé entre Secession-la traduction d'Erín Moure du galicien vers l'anglais d'un livre de la poète Chus Pato-et Insecession-le texte-écho que Moure signe en partie pour lui rendre hommage. Ces deux textes sont publiés au Canada dans une édition conjointe qui s'intitule Secession/Insecession (BookThug, 2014). Je fais en outre une lecture de Absence Where As (Claude Cahun and the Unopened Book) de Nathanaël (Nathalie Stephens), oeuvre où l'auteure réfléchit sur sa relation vertigineuse à une photographie de Claude Cahun et au constat que, dans Cahun, elle se ressemble. Dans ces deux corpus, je m'intéresse à l'inclination d'un texte vers un autre et aux différentes possibilités d'échanges qu'une telle lecture peut offrir à la traduction. Alors que ces textes s'ouvrent à un jeu de correspondances plutôt qu'à une pratique d'équivalence, la traduction, à l'instar de ces exemples, devient un lieu privilégié pour une réflexion sur le va-et-vient des textes, leurs relations multiples et les réseaux d'inclination entre eux. 


\title{
Letters On The Move: Erín Moure and Chus Pato's Secession/Insecession and Nathanaël (Nathalie Stephens)'s Absence Where As (Claude Cahun and the Unopened Book)
}

\author{
Geneviève Robichaud
}

The poem writes what's not yet there. Chus Pato, Secession, 20I4, trans. Erín Moure

\section{INTRODUCTION}

want to begin with a question, as it is a question I find myself asking over and over:

How or where, under what circumstances, do texts meet and collide? How or with whom do they move? When I ask these questions, I have in mind something of translation. For instance, when I open a recent book-length essay on translation by the experimental feminist and Québécoise poet Nicole Brossard, I stop at the very first sentence and the very first question she poses: "Pourquoi la traduction?" I Why translation? In reality, the sentence does not end where I pretend it does. Instead it has a much lengthier itinerary: "Pourquoi la traduction n'est-elle pas un sujet comme un autre, je veux dire en quoi prédispose-t-elle à une authentique ferveur du sens, allant parfois jusqu'au débat, comme si en chaque mot se cachait un enjeu de vie, une vision du monde miniaturisée?" 2 What I retain from the full-length question is that whatever translation reveals, it seems it has less to do with translation itself than with an internal agitation in words, as though each were a keeper of a secret thing whose visibility (or secret life) is sometimes glimpsed in translation. In that sense, one might add that whatever is revealed in translation, or whatever translation grants to vision, something of translation is always also necessarily invisible.

For feminist writers and critics, like Nicole Brossard, who were working on questions of language and subjectivity, the question "why translation" became,

\footnotetext{
${ }^{\mathrm{I}}$ Nicole Brossard, Et me voici soudain en train de refaire le monde, Montréal, Mémoire d'encrier, 2015 , p. 7.

${ }^{2}$ Ibid.
} 
beginning in the late 1970s, intrinsically linked to issues of (in)visibility-morphing the question of "why" into the question of "how": how can one rethink the role of translation, writing, and reading; how can language and literature alter or mark one's presence in the world? The critique was directed towards patriarchal language and its effacement of women's realities. This led many feminists to work on language-focused texts of a highly experimental nature. In their desire to mark the gendered spaces produced in both linguistic and social contexts, the turn to literary translation offered a potentially empowering form of writing where women's experiences could find an anchor point in the agency of their reading and rewriting of texts often created by other feminists. In so doing, they created and appropriated for themselves an écriture an féminin, which echoed the poststructuralist écriture féminine of Julia Kristeva, Monique Wittig, Hélène Cixous, and Luce Irigaray, all of whom placed theory at the centre of their writing. "Do the translations seek to hide the work of translation and appear as naturalized in the English language, or do they function as texts, as writing, and foreground their work upon meaning?"3 That is the distinguishing question posed by the late Barbara Godard, whose work, both as feminist translator and as one of feminism's most eminent theorists, not to mention her various editorial contributions in promoting bilingual feminist literary production across Canada, ${ }^{4}$ helped establish and legitimize a highly experimental feminist translation practice and poetics in English Canada and in Quebec.

With feminist theory on the one hand and a distinctly feminist poetics on the other, Godard helped theorize translation as a site of exchange and collaboration.

3 Barbara Godard, “Theorizing Feminist Discourse/Translation," Tessera, vol. 6, Spring/printemps 1989, p. 43.

4 I am thinking here particularly of her involvement with the bilingual feminist journal Tessera (1984-2005). Although Tessera devoted the entirety of its volume 6 (1989) to the exploration of translation, almost every issue in its lifespan included some element of translation (either in theory or in content). Tessera was also a notable language-oriented literary magazine in its dedication to showcasing experimental and theory-driven writing. As is explained on the home page of its archive hosted by York University, "at the outset, the editors wished to present the innovative feminist theoretical writing being developed in Quebec to English Canadian critics and writers; by so doing, it fostered the development of 'fiction/theory,' the term coined in the third issue to name this body of experimental writing. Tessera created a dialogue between French and English speaking women writers and theorists by publishing in both official languages and providing a précis for each text in the opposite language," http://tessera.journals.yorku.ca/index.php/tessera/index (accessed Dec. I3, 2016). 
Thinking of these collaborations as double movements between "re/reading and re/writing" practices, she argued that the presence of the slash in re/reading and re/writing both demarcates and blurs the boundaries between reading and writing, writing and translating. Pointing to the example of Brossard's Le Désert mawve, s Godard described translation as a "dialogic moment [...] underlining the double activity of women's writing as reading/writing, as the re/reading of the already-written followed by the divining/writing of the unrecorded." 6,7 Shifting her attention to reading and writing as acts of production, and therefore as performative, translation, in Godard's view, becomes an act of transformance, ${ }^{8}$ a term she uses to "emphasize the work of translation, the focus on the process of constructing meaning in the activity of transformation, a mode of performance." In transformance, translation becomes an active site of exchange, a place for (writing as) thinking, where the translator is an agent and the translation is an act of production rather than simply the site where equivalencies are maintained or where a copy or reproduction of an original takes place.

Returning for a moment to the why of translation that opened this study, it is worth pointing out that for Brossard the why of translation soon overlaps with the how of creative writing: "Aussi m'arrive-t-il de projeter sur la traduction des réflexions élaborées en pensant à la création littéraire." ${ }^{\circ}$ And shortly thereafter the question of how also becomes a question of who: "Toute traductrice, tout traducteur est d'abord une lectrice, un lecteur, c'est à dire quelqu'un qui fait entrer dans son monde intérieur un autre monde avec ses mystères, ses ambiguïtés, ses fulgurances, ses zones

5 Nicole Brossard, Le Désert mauve, Montréal, L'Hexagone, 1987.

${ }^{6}$ Godard, 1989, p. 46.

7 For a more detailed reading of Godard and Brossard's author-translator relationship as well as a book-length study on gender and translation see, among others, Sherry Simon's Gender in Translation: Cultural Identity and the Politics of Transmission, London, Routledge, 1996.

8 "Transformance" is also the term used to describe the re/writing project between Nicole Brossard and Daphne Marlatt. See Daphne Marlatt and Nicole Brossard's Mauve, Vancouver, Montreal, nbj/writing, 1985 and Character/Jeu de lettres, Vancouver, Montreal, nbj/writing, I986.

9 Godard, 1989, p. 46.

1o Brossard's invocation of creative writing here serves as a further example of the blurred boundaries between writing and translation I had previously gestured to, not only in terms of a creative approach to translation, but also to a move away from hierarchizing the act of writing as supposedly distinct or superior to that of translating — as if translating is not writing. 
dangereuses." "II This attention to the reader and to what, or who, enters is where I wish to begin thinking about how and on what poetic terrain the translative (act) — as a form of movement/correspondence-might constitute itself. In an essay entitled "Performing Translation," ${ }_{22}$ Sandra Bermann suggests that the "act" of translation entails a certain inclination on the part of the translator such that

the translator inclines toward the language and conventions of the source in order to translate them into her own very different language. A new linguistic production results, one infused with the otherness of its source. In ways such as these, translation's ostentatious iterability reveals a quite uncanny potential for literary action, presenting a text from elsewhere to a new audience, while creating a new language that will, in some sense, belong to (and disrupt) them both. ${ }^{13}$

Following Bermann's figure of the inclined translator and translation's "potential for literary action," this article examines two works where the inclination of creative writing practices and translation participates in a double movement between re/reading and re/writing. The first is Secession/Insecession, which is Erín Moure's 2ors English translation of Chus Pato's Galician biopoetic 2009 text Secession, or rather Secesión, published alongside Moure's own "echolation-homage," response or reciprocation, Insecession. ${ }^{\text {I4 }}$ The second work, Nathanaël's Absence Where As (Claude Cabun and the Unopened Book), ${ }^{\text {is }}$ is an essay instigated by the author's relationship to a photograph of and by Surrealist photographer and writer Claude Cahun where, faced with a self-portrait of the artist, Nathanaël is surprised to find that in Cahun she resembles herself. Thus, in pursuing the inclined (dis)position of/in both Moure's and Nathanaël's texts, as Moure tends towards Pato through the figure of the slash (a typographical manifestation of the incline), and as Nathanaël tends towards what is

\footnotetext{
II Brossard, 20I5, p. IO.

${ }^{12}$ Like Barbara Godard, who likened translation to an act of production, Bermann proposes translation as a form or act of doing that requires the translator to act or "'perform' a source text for her new public." In turning her interest to the "something translation does," she reads the "performativity" of translation through language and gender studies, linguistic and cultural difference as she works through the theories of Austin, Derrida, and Butler. See Sandra Bermann, "Performing Translation," in Sandra Bermann and Catherine Porter (eds.), $A$ Companion to Translation Studies, ${ }^{\text {st }}$ ed., West Sussex, Wiley, 20I4, p. 285.

i3 Ibid., p. 290.

${ }^{14}$ Erín Moure and Chus Pato, Secession/Insecession, Toronto, BookThug, 2014; Chus Pato, Secesión, Vigo, Editorial Galaxia, 2009.

is Nathanaël (Nathalie Stephens), Absence Where As (Claude Cabun and the Unopened Book), New York, Nightboat Books, 2009.
} 
revealed of herself in Cahun's photograph, causing her to experience a kind of vertiginous perspective as the image opens onto an abyss, this study asks: What does it mean to write on an incline? To bend inwards or towards? Must the translator's inclination, like a slash, divide the reading from the writing? The response from the resemblance? The echo from the écart? Or might the translator pivot on the slash, as Bermann seems to suggest, simultaneously marking belonging and also disruption? Considering the nature of the double in these texts, as an inclination or slash must necessarily divide or link (co-respond), I remain close to Brossard's suggestion that in translation one lets the other in (faire entrer dans son monde intérieur), such that framing the response, reciprocation, and resemblance of one text to another-to borrow the language used earlier to describe Moure's relationship to Pato's text as well as Nathanaël's to Cahun's-I echo Brossard in asking: “Que ferai-je de toi une fois que tu seras entrée dans mon univers? Irons-nous quelque part ensemble? Jusqu'où?”'16, I7

\section{MARKING ARRIVALS AND DEPARTURES: WHAT IS SECESSION/INSECESSION?}

An initial response to the question what is Secession/Insecession might be this: Insecession is the Canadian poet and translator Erín Moure's response, or "echolationhomage and biopoetics," to her Canadian English translation of Galician poet Chus Pato's biopoetic text, Secession, "with one added Chinook wind." 18 While I shall come back to the "added Chinook wind," for now I want to add a few more details to describe the way I receive/read the book.

First, there is the fact that in Secession/Insecession Moure's and Pato's texts face each other-with Pato's Secession on the right and Moure's Insecession on the left. Second, there is Moure's neologism "echolation-homage." In "echolation" the ghost of the words "echo," "elation," and "echolocation" floats above the newly claimed

${ }^{16}$ Brossard, 2015, p. 13.

${ }^{17}$ At this juncture I would like to point out that I have chosen to place my thinking and therefore the writing of this article on an incline- not annexing my words to the works in question, but allowing the texts to work on the contours of my thoughts and writing. The result is an article that embraces a response to the texts with a style some might associate with a feminist theory of reading, while for others the style of the writing/thinking might simply denote a more creative approach.

${ }^{18}$ Moure and Pato, 2014, p. 6. 
expression like a kind of three-dimensional technology, presencing Insecession's disposition, or dispositif if we are to think of translation as technology, as transmission, as broadcast system, or as a form of response to the vibrations or sound waves in Pato's text: "I really want to investigate the relation of transmissibility [...]. The relation of texts to bodies." ${ }^{19}$ Why the language of three-dimensionality? Because there is, in the compression of the word, a world of words that simultaneously collapse (et qui s'étendent) into one another, like a landscape, or that lurch forward leveling the terrain of the word into semantic space rather than anything remotely linear. But that is not all. Given the very specific kind of title Moure grants to her response-text, it is difficult to ignore that she also interweaves Insecession with Secession, meaning that the two not only face each other, but that one is also nestled in the other:

The slash is a graphic way of presenting a bicephalous book: our titles appear as equals. Although Pato's biopoetics Secession, in this edition, is interwoven with my own Insecession, it is in no way subordinate to my text, but is its very cause, its precursor and its most precious interlocutor. Insecession is my biopoetics nestled "in Secession." They appear "with" each other because they are friend texts, reverberative. ${ }^{20}$

That graphically the incline of the slash suggests they are equals does not necessarily amount to an equal exchange between the two texts. While they appear together as "friend texts," it is difficult to ignore that both texts are in English, and that Insecession, as an homage and response-text, exists in excess of Secession as it is derived from it. As Moure herself suggests, Insecession is caused by Secession. But my use of the word "excess" need not carry negative connotations. Instead what I wish to remark upon is the idea that the graphic inclination of the slash separating the two titles allows Moure's and Pato's texts to claim their own space, their own biography (biopoetics), all the while permitting Moure to show that, as the translator, she is invariably also nestled in her translation of Pato's Secesión into Secession, and that, as a reader of Pato, Insecession inevitably folds out of her reading/translation of Secession. As Nicole Brossard, writing about the very work under discussion here, observes: "À vrai dire, Erín Moure met en scène ce qui jusqu’à maintenant était resté sous-entendu: moi, traductrice poète, je vis, j'entends et je réponds à plusieurs niveaux à ce que je traduis; bref, dans chaque traduction, je réponds à ma propre vie de réel et de pensées." ${ }^{21}$ The

${ }^{19}$ Ibid., p. II2.

${ }^{20}$ Erín Moure and Geneviève Robichaud, "Geneviève Robichaud in Conversation with Erín Moure,” Lemon Hound, July 2014, http://lemonhound.com/2014/o7/o7/genevieverobichaud-in-conversation-with-erin-moure/ (accessed May 30, 2016).

${ }^{21}$ Brossard, 2015, p. 55 . 
"in" of Insecession, then, as I have previously remarked, is interesting to pause on, as it figures the slippage from one work to the other-from Secession to In-Secessionmarking not only what seems a series of arrivals and departures, but what Brossard has alluded to, in our introduction, as the secret life of words (see Fig. I-2).

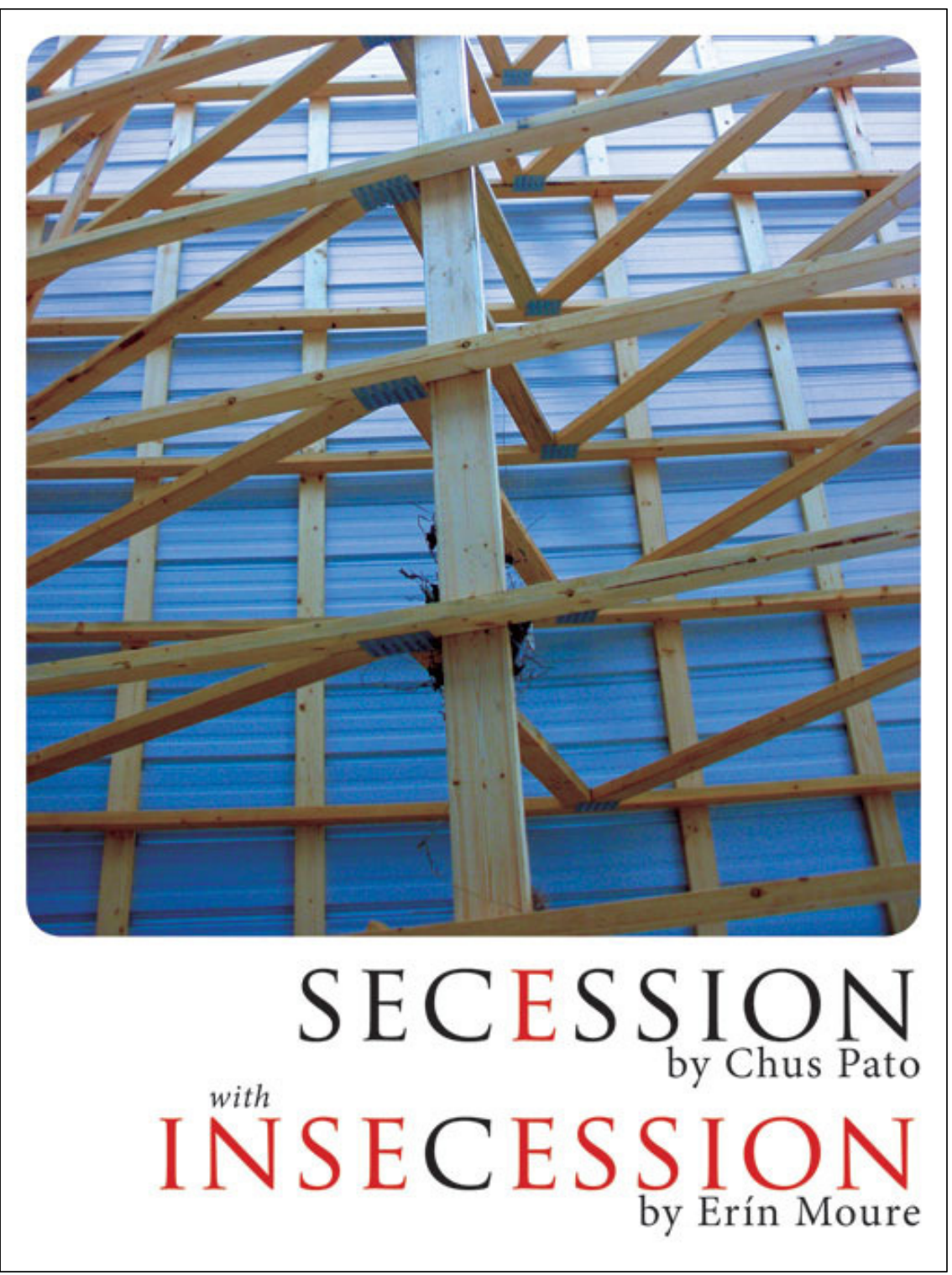

Fig. I. Book cover of Erín Moure and Chus Pato’s Secession/Insecession (BookThug, 2009). (C) BookThug 


\section{SECES SION \\ the Erin Moure translation}

IN Nith $\mathrm{N}$ E C $\underset{\text { ber Chus Pato echolation }}{\mathrm{ES} S \mathrm{~S} \text { Erín Moure }}$

A Sample from the text

BookThug $\cdot 2014$

INSECESSION

Erín Moure

INSECESSION

\begin{abstract}
An echolation-homage and biopoetics by Erin Moure, Montreal poet born the same year as Chus Pato,

in a city traversed by two rivers, just east of the Canadian Rockies.

Each text in Canadian English responds to a Pato text,
\end{abstract}

with one added Chinook wind.

Erin Moure thanks Chus Pato and Jay MillAr
A readerly text is one I cannot re-produce (today I cannot write like Atwood); a writerly text is one I can read only if I utterly transform my reading regime. I now recognize a third text alongside the readerly and the writerly: let's call it the intranslatable. The intranslatable is the unreaderly text which catches fire, burns in the mouth, an instance continuously outside any likelihood, whose function - ardently assumed by its scripter - is to contest the mercantile constraints on what is written. This text, guided, armed by a notion of material, prompts me to redact the following words: Dear Chus, I can neither read nor write what you produce, but I can intranslate it, like a conflagration, a drug, an insecession, an e(ri)nigmatic disorganization.

Roland Barthes by Roland Barthes

Richard Howard translation,

altered by Ruin E. Rome We recognize altitude as we ascend, we call the ocean that unfolds below:
Canadian Rockies

Translation pivots on the word - as painting does on paint - this word that is not ours makes us feel, infects us... a translator's gaze, a painter's, are authentic mutations, and thus their works can cross the gap between word and meaning paint and gaze

translation, to sustain Literature, does not disdain or push away what rejects it and never disguises silence, it touches our interior, the mochine of our organs, magnetizes the black holes of the language, potentates meaning

because of this, the deer fie in a space of light and murmurs

-the deer are in the aspens?

- circles mark the grass amid the aspens where they have lain

- did they die?

$-n$, they awoke to glean

-when you translate Chus Pato, where are you?

-in the starting air, in the no-event: on Air Galicia, for example

-and when you write your own poems?

-in the continual fold of the event

where words are ecstatic figures and unjudgeable, marred and irretrievable, which is to say, amid the aspens
SECESSION

Chus Pato

SECESSION

A biopoetics by Chus Pato, Galician poet from Ourense, Galicia in the green Atlantic climate of the northwest of Spain, Europe.

Transiated from the Galician

into Canadian English

by Erin Moure
A readerly text is one I cannot rewrite (can I write today like Balzac?); a writerly text is one I read with difficulty, unless I completely transform my reading regime. I now conceive that there may be a third text: alongside the readerly and the writerly, there would be something like the receivabie. The receivable is the unreaderly text which catches hold, the red-hot text, a product continuously outside any likelihood, whose function - visibly assumed by its scripter - would be to contest the mercantile constraint of what is written; this text, guided, armed by a notion of the unpublishable, would elicit the following response: I can neither read nor write what you produce, but I receive it, like a fire, a drug, an enigmatic disorganization.

Roland Barthes by Roland Barthes Richard Howard translation

We recognize altitude from elevation, we call the most extensive prairie: Ocean

Literature is based on the word - as the visual arts are on the gaze this word that is not ours makes us feel, commits us... a painter's eyes, a filmmaker's, are authentic mutations, and thus their works ring true

the word that sustains Literature does not disdain or push away what rejects it and must not be confused with silence, it touches animality and machines, magnetizes the stars of the language, polarizes meaning

because of this, lovers lie in the hugest of intervals

-the lovers are in the circle?

-the circle marks where they had lain

-they died?

-they died?
- of course

- of course

-in the unexpected, in what will never occur: being a trapeze artist, for example

-and when you write?

-in what occurs, in what continually takes place

so, words are free to be extreme figures and unjudgeable, irreparable

Fig. 2. Erín Moure and Chus Pato, Secession/Insecession, Toronto, BookThug, 2014 (online sample). C BookThug 
In the sense of a va et vient, the slash, like Moure's use of the prefix “in," is a capacious symbol able to register both Moure's affective choices as reader/translator as well as Pato's influence on her work: "Translation ('the poetry of Chus Pato') is a way of bringing - into the secession or cut - another voice, her human voice, markings in words from a culture across a far border, to mark these words (her words) into new ears and onto new bodies." ${ }^{22}$ Furthermore, although the bicephalous quality of the book rewards a reading that notices the ways in which one text arrives or departs from the other, for now, however, I want to underline the idea that, if the titles appear "with" each other, as Moure suggests, and if the relationship between the texts allows her to make herself visible (as writer, reader, and translator), then the cut implied by the slash also opens onto a third text. This reading of a third text equally resonates with the fact that Pato begins Secession with a quote by Roland Barthes on the unreaderly third text, which he terms "the receivable":

A readerly text is one I cannot rewrite (can I write today like Balzac?); a writerly text is one I read with difficulty, unless I completely transform my reading regime. I now conceive that there may be a third text: alongside the readerly and the writerly, there would be something like the receivable. The receivable is the unreaderly text which catches hold, the red-hot text, a product continuously outside any likelihood, whose function-visibly assumed by its scriptor-would be to contest the mercantile constraint of what is written; this text, guided, armed by a notion of the unpublishable, would elicit the following response: I can neither read nor write what you produce, but I receive it, like a fire, a drug, an enigmatic disorganization. ${ }^{23}$

Moure, for her part, under the heteronym "Ruin E. Rome," an anagram of her name reserved only for this epigraph, playfully alters Barthes' passage in Insecessionallowing the quote to traverse her corp(us)s_not unchanged—and not unlike her “e(ri)nigmatic disorganizations” of Pato's text:

I now recognize a third text alongside the readerly and the writerly: let's call it the intranslatable. The intranslatable is the unreaderly text which catches fire, burns in the mouth, an instance continuously outside any likelihood, whose function-ardently assumed by its scripter-is to contest the mercantile constraints on what is written. This text, guided, armed by a notion of material, prompts me to redact the following words: Dear Chus, I can neither read nor write what you produce, but I can intranslate it, like a conflagration, a drug, an insecession, an e(ri)nigmatic disorganization. ${ }^{24}$

\footnotetext{
${ }^{22}$ Moure and Pato, 2014, p. I44.

${ }^{23}$ Roland Barthes, quoted by Pato in Moure and Pato, 20I4, p. 9.

${ }^{24}$ Moure and Pato, 20I4, p. 8.
} 
Despite their mediated appellations, both terms-Barthes' "receivable" and Moure's "intranslatable"-gesture towards a fictitious third text that dwells in-between or rather alongside the readerly and writerly one, ${ }^{25}$ and which incites me to gesture to the symbol of the slash as a visual manifestation of what would otherwise remain invisible as it can only be received or in-translated. Put another way, of the third text that exists alongside the readerly and writerly ones, "receivable" and "intranslatable" register what is produced in the reader: a desire, a tiny shock, an entire world (moving) - in short, a thing in perpetual becoming. This is one of translation's most generous attributesthat it does not act alone: "double personnalité, dirons-nous," writes Brossard in relation to literature's (not psychology's) dream of being another, "je te lis dans une langue étrangère, je t'emporterai avec moi dans ma langue maternelle. Je est toujours un autre en devenir." ${ }^{26}$ This idea of the self as an other will become even more prominent when we turn our attention to Nathanaël's relation to Claude Cahun.

Marking the exchange between her own and Pato's work-making Pato's influence visible in her own writing by allowing Pato's writing to be accessible to readers who cannot read Galician - the slash in Secession/Insecession sets an example for a greater opening up of the literary spaces that shape us as writers and readers as it enlarges what Brossard calls "les cercles d'intimité qui s'offrent dans la mise en œuvre d'une traduction." ${ }^{27}$ Yet, when Moure enlarges her "cercle d'intimite" by bringing Pato into the fold, and when she makes Pato visible to English readers, it is not simply a way for her of confirming what Brossard describes as "la rencontre née d'une lecture intense [qui] altère, confirme, renouvelle notre façon de voir et de ressentir la réalité,” although it certainly is part of it. ${ }^{28}$ While Pato's arrival via Moure's English translation of her work molds and morphs the dual form Secession/Insecession takes, the shape of the

25 The readerly text (lisible) is one that does not make demands on the reader as its meaning is presumed to be fixed-a meaning which is intact and waiting to be extracted, turning the reader into a passive consumer of that information (for example, the realism of nineteenth century novels). These texts, according to Barthes, are concerned with storyline and therefore demand a horizontal reading; the writerly text (scriptible) is the text that is always in production, is open, self-conscious, and where the reader becomes an active participant in its meaningessentially blurring the line between the reader and the writer (for example, the work of modernist experimental literature). These texts require a vertical reading that imparts a reading of bliss or “jouissance” on the reader. See Roland Barthes' S/Z, Paris, Seuil, I970.

${ }^{26}$ Brossard, 2015, p. 13.

27 Ibid.

${ }^{28}$ Ibid., p. 17 . 
book also makes visible Canada's restrictive public policy in regard to the financial support for publications of foreign literary translations by Canadian translators. Though my reading of the slash has, until this point, been sparked by its creativity and ardour, I have done so without addressing a crucial aspect of the book: Moure's insistence in the prefatory notes that each text in Insecession "responds to a Pato text, with one added Chinook wind." 29 I now want to address that claim.

First, what are Chinooks and why does Moure insist that she has added one in Insecession? Chinooks are warm coastal winds that blow where the Canadian Prairies and Great Plains meet various mountain ranges. In relation to Secession/Insecession, these winds blow us all the way to funding agencies, like the federally based Canada Council for the Arts, which supports the Canadian publishing industry and independent publishers by offering various programs and subsidies. Publishers, like Secession/Insecession's BookThug in Toronto, can receive support for their publication of books in translation as long as they fit the following criteria: "[For publishers] this program provides grants for the translation of literary works written by Canadian authors." ${ }^{30}$ To be eligible, a book must "contain at least 50\% Canadian-authored creative content; have at least 48 printed pages between the covers [...], be published principally in English, French or one of Canada's Aboriginal languages." ${ }^{31}$ Publishers, then, cannot receive financial support from the Canada Council for the Arts for the publication in Canada of international translations done by Canadian translators. Of consequence here is the manner in which the funding policies explain the dually authored nature of the book. In order to be eligible for a Canada Council translation grant, Moure's publisher requires that Moure transform her translation of Secession into "Canadian-authored creative content." This, of course, is due to the fact that even though technically it is not Pato who wrote Secession-Moure's English Canadian translation-funding policies do not make these distinctions and so Moure must invent a new book to accompany her translation of Pato's. She does this not only by writing her own accompanying text, which acts as an echo and homage to Pato, but by

${ }^{29}$ Moure and Pato, 20I4, p. 6.

30 "Book Publishing Support: Block Grants," Canada Council for the Arts, http://canadacouncil.ca/council/grants/find-a-grant/grants/book-publishing-support-blockgrants (accessed Nov. 2I, 2016); see also "Book Publishing Support: Translation Grants," http://canadacouncil.ca/writing-and-publishing/find-a-grant/grants/book-publishingsupport-translation-grants (accessed Nov. 2I, 20I6).

${ }^{31} \mathrm{Ibid}$. 
also making Insecession one text longer than Secession. In this way, the now bicephalous title Secession/Insecession is sure to qualify as Canadian since Moure can be counted as the author of more than half of the book. ${ }^{32}$ The Chinook wind, then, is the text that appears at the end of Insecession - the one entitled " 48 , OR 49 " - and that does not share a corresponding text with Pato (remember that in order to qualify as Canadian the book must "have at least 48 printed pages between the covers"): "I still owe 48 words, $47+\mathrm{I}$ so the book will be Canadian $+\mathrm{I}$ missing from 'Lgiht's End'." 33 (See Fig. 3)
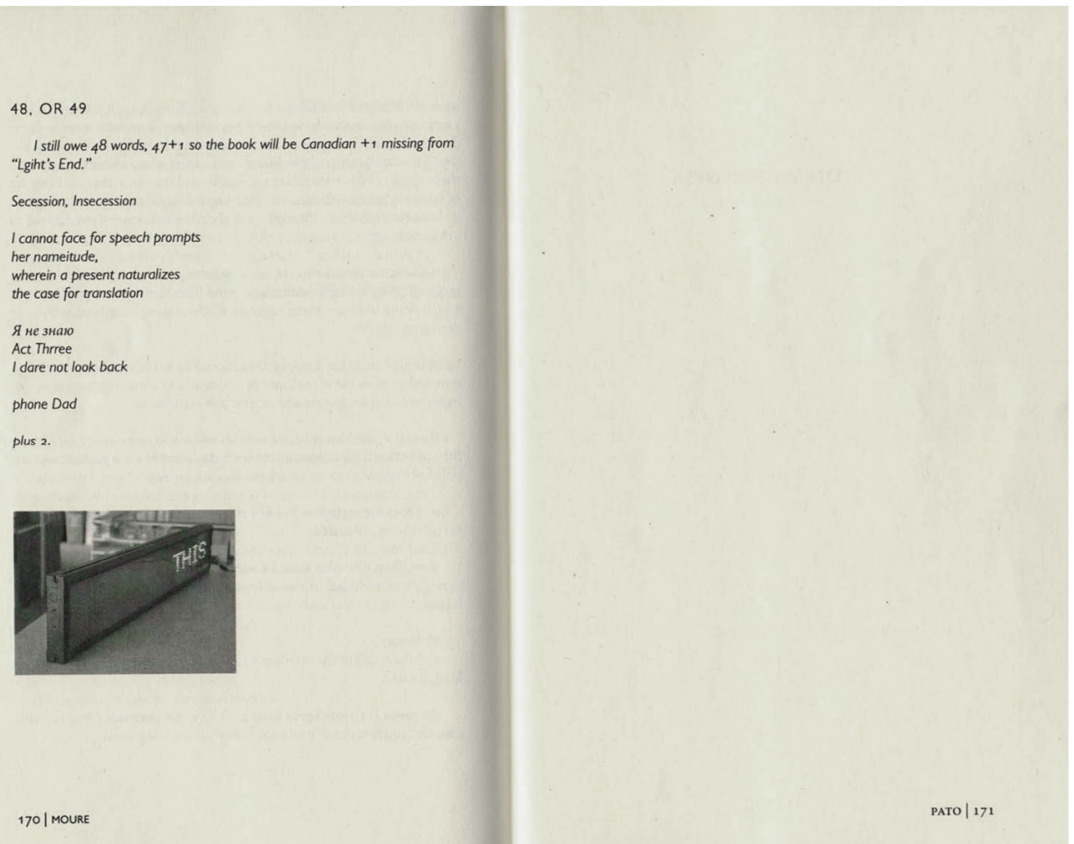

Fig. 3. “48, OR 49,” Erín Moure and Chus Pato, Secession/Insecession, Toronto, BookThug, 20I4, p. I70-I7I. Image scan by Geneviève Robichaud.

(C) BookThug

${ }^{32}$ For Moure's discussion of these issues, see Christina Davis, "'Outside the Fold': A Conversation with/without Erín Moure and Chus Pato," Stylus: The Blog of the Woodberry Poetry Room, Dec. 17, 20I5, http://woodberrypoetryroom.com/?p=1904 (accessed Dec. I3, 2016); Erín Moure, "Translation and Its Affective Challenges: Bodies, Spacings and Locales from the Okanagan to the Deza, from Canada to Galicia," Evening Will Come: A Monthly Journal of Poetics, no 55, July 20I5, http://www.thevolta.org/ewc55-emoure-pi.html (accessed Dec. I3, 2016); and Moure and Robichaud, 2014.

33 Moure and Pato, 2014, p. I7o. 


\section{Nathanä̈l's Claude Cahun: The Photograph as Abyss}

In Nathanaël's Absence Where As (Claude Cabun and the Unopened Book), there is also something of a slash in the ambivalent relationship she shares with a 1930 photograph of Surrealist photographer and writer Claude Cahun. Neither parallel nor consisting of an oblique relation, the link she draws to Cahun is rather one that joins and disjoins; it is one of overreach, of extension, like the parentheses of the title (Claude Cabun and the Unopened Book), which brackets the encounter, delineates it as an elsewhere, a sub-title. But it is not only Cahun who appears in the insertion of the parentheses. Beside her signature, Nathanaël (Nathalie Stephens) too is bracketed (intercalée), as though like the unopened book that carries the promise of being split open, the two names, which do not touch, might also in some temporal elsewhere collapse into one another. When read as an echoic construction, the parentheses invite a reading that confounds (equates) the ambivalence of an absence (where as) with an absence (whereas). The former records a spatial rupture, the latter a temporal one. With Nathanaël's passage from Nathanaël to Nathalie Stephens, the double passage ${ }^{34}$ incites a reading of extensions and, what is more, of liminality, as it is impossible to say at which moment (or where) one enters/exits the parentheses: "I insist on that which is liminal, delineates and distends, distorts and denies. What imposes itself littorally if not laterally between two places (at least). What escapes us, and from which we do not escape [...] I make (myself): envoi."35

Here, I invite several resonant connotations to inflect my reading of extension, namely in the (transitive) sense of to extend (as one outstretches one's hand towards someone, or as a gesture extended as one risks one's self in the reach towards an other). This reach, as an invitation to an elsewhere that one must traverse, is made palpable in the opening of "Fa ille," the first of three sections, this one consisting of twenty-two parts, and which is subtitled "(I) Envoi:" "I will speak to you of a relation, possibly of a liaison, most certainly of a correspondence. ${ }^{36}$ I write aptly because in French an envoi (envoyer quelque chose, une lettre) already introduces the suspension and distance of

34 I leave undeveloped here, in the language of double passage, a comparative reading of L'absence au lieu (Claude Cabun et le livre inowvert) (2007), except to motion towards the idea that there are multiple doubles co-lapsing in the work(s), between and across them (it), and which befits a reading of versions, each one furthering the other, rather than a reading of copies.

${ }_{35}$ Nathanaël (Nathalie Stephens), 2009, p. 4.

${ }^{36}$ Ibid., p. 3. 
the reach (of a letter sent [out]), and it is precisely in the space of the envoi, of correspondence, that Absence Where As figures the ambivalence of encounter (is it me or you who advances, comes, moves towards the other?): "before even risking ourselves, we are called to gauge these capricious disturbances, to say yes, and what's more, however." 37 But just as the envoi must reach across its own dislocation, intent on joining (fixing) what escapes it (for now let's say what dis-places), it must also confront its own liminality (as that which cannot be wholly situated) and where there remains "the uncalculated, uncalculable part, agitated, detached from the place from which it is propelled and toward which it goes, [and which] is uncomfortably settled in the liminal space of the envoi, the gesture soliciting an other, the proximity inadvertently availed of such an inclination." 38

The language of remains is quite essential to my reading of the book. The word figures both something of death (bodily remains), but also of something left over, ${ }^{39}$ something in a state of becoming. It is the latter signification, in the sense of a remainder, that I want to focus on here. On a facsimile of a handwritten note (a letter), most likely (torn) from the grid-papered notebook acquired from the Art Institute of Chicago-that other book that comprises one of the two constitutive parentheses placed at the rightmost end of Nathanaël's bookshelf (Cahun's unopened book being on the leftmost end)-lies tucked in the middle of the book (the book I [we] are reading), the following French passage: "fondement langagier édificiel: s'il ne l'est pas déjà, il est en voie de devenir un reste, un vestige, une ruine (ce que nous sommes) / Folie / le passage du rien au rien." ${ }^{\circ}$ The passage is accompanied by a drawing of an edifice, the same edifice that garners the cover of the book, along with the handwritten word "folie" (see Fig. 5-6). What is this passage into language as becoming and as remainder, as madness, but two unopened books, one that prompts the very essay we are reading, and that "remains to be read," the other "which contains not a trace" both of which seem to stage a vision of the double object of encounter, le passage $d u$ rien au rien, and the promise (spectral), though we do not always know what (in advance, or as it advances towards us) will hook us, demand (of) us:

37 Ibid., p. 4.

${ }^{38}$ Ibid., p. 3 .

39 There is, in fact, a whole section at the end, fragments, which carry the title "(Remains)." Ibid., p. 9 I.

40 Ibid., p. 66. 
The constitution of the shelf visible from my work table is determining. There are those books whose selection is governed by an affective consideration-my attachment to an author, a period of time, a place, encounter, a sensibility-without neglecting the importance of a text in my trajectory, the impulses that formulate it. [...] To each place its markers, its demands, which only reveal themselves at the moment of installation, of both body and furniture, and not a minute before. Books, like artworks, are the last elements to find their place-in transit, in passing, from their dispersal to their derangement. ${ }^{\mathrm{I}}$

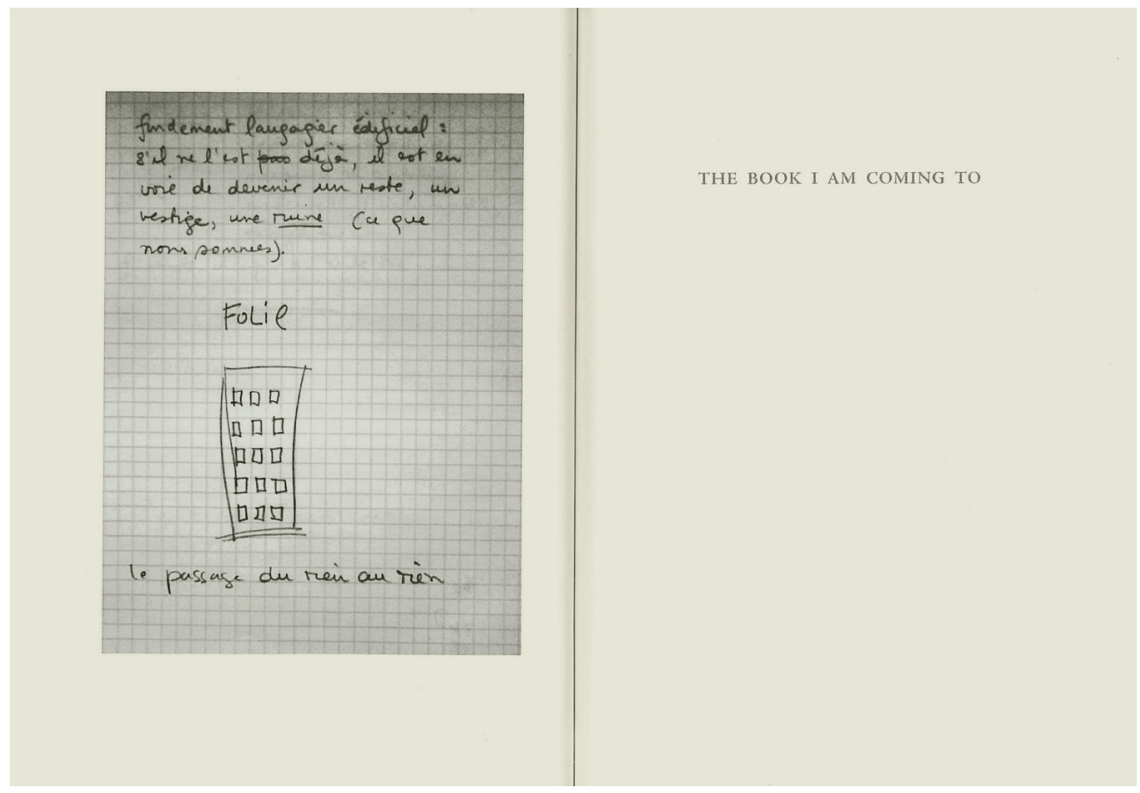

Fig. 5. Nathanaël (Nathalie Stephens), Absence Where As (Claude Cabun and the Unopened Book), New York, Nightboat Books, 2009, p. 66-67. Image scan by Geneviève Robichaud. (c) Nightboat Books

As Nathanaël goes on to point out, however, "to each rule its exception," to which I would add that that is precisely what, in some cases, a remainder can come to mean: an exception. ${ }^{42}$ In the case of Absence Where $A s$, there are at least two such exceptions: on one end of the library shelf there is, as I have mentioned, the gridpapered notebook "still in its wrapper, where no mark or trace inscribed," signifying pure potential (a promise of what is to come), and on the other end "that mastodon, Écrits, by writer and photographer Claude Cahun, which, since it has been following

\footnotetext{
${ }^{41}$ Ibid., p. Iо.

${ }^{42}$ Ibid., p. II.
} 
me, pursuing me, remains unopened. At any rate until the moment at which I agreed to speak of it, to open what had remained closed, in other words what was inevitable and unbearable, but so imperative." 43

\section{ABSENCE WHERE AS}

(CLAUDE CAHUN AND THE UNOPENED BOOK )
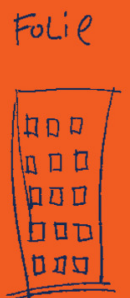

Narhanä̈l ( Narhalie Srephens )

Fig. 6. Book cover of Nathanaël (Nathalie Stephens), Absence Where As (Claude Cabun and the Unopened Book), New York, Nightboat Books, 2009.

(C) Nightboat Books

That word again: remains. And it is exactly where one might expect to find it, in the exception - in the book that "inaugurates the movement of the whole collection, the book I am coming to, and which comes to me to introduce disturbances and recriminations into my work space, fateful reminder of disjunction and disappearance-of erasure [...] Écrits." 44 Between two parentheses: the book "[which] occupies a place of suspension, projected quite possibly by the body that intervenes as

$$
\begin{aligned}
& { }^{4} \text { Ibid. } \\
& 44 \text { Ibid. }
\end{aligned}
$$


it approaches, and as soon as it thinks it has situated itself, collides with a whole other function of the text," and the gesture of writing (the envoi figured also in the scrap of paper torn from the notebook), which "far from being locatable in the body, floats between it and the book, suspended in space [...] making of the intermediary the immediate against which I (JE) defend myself." 45

There is another form of exception that presses on me, on my reading, and that takes the shape of a letter, which escapes, is made absent, emptied out. I am thinking here of the scission of the letter $m$ - that incalculable or invisible part to echo Brossard's secret life of words-detached and reaching across the place from which it stood (fixed, unfixed), and which anticipates the (b)reach established and reiterated throughout the book-between what seems at first a minute distance between two terms, "la famille (the family)" and "la fa ille (the fault line...flaw...rift)." ${ }^{6} 6$ With the absence of the letter $m$, the fault line (écart) or breach between the two words as well as the one enacted in the word faille do more than merely disrupt the social mythology of "family" bonds and its presupposed origin, order, or fixed trajectory; instead, such an écart (rift) anticipates a different kind of trajectory, one that is furtive, deviant (as it deviates from an origin), unexpected, and that fixes its gaze, quite littorally, ${ }^{47}$ as we shall soon see, in the photographic "encounter" between herself and Cahun. ${ }^{48}$

The encounter reintroduces the ambivalence of the parentheses in the title where the author is not only double (Nathanaël and Nathalie Stephens), but wrenched from any determining location-allowing Nathanaël to render herself elsewhere (to a here there) as she extracts herself "from the moment riveted to its materiality, the architectured, temporal space made precise by a name, an arrangement of buildings cobbled onto a dismantled horizon, a situation, a location, a there." 49 Here, in the space of the envoi, an architectured and temporal space brackets the encounter into a there" $[t]$ bere where I put my hand. There where I close the door behind me. There where I unpack my bag. There where place incites me, chides me invites me"-but it is a there that, as it breaks from normative time in its suggestion of (at least) a double, also empties (faults) itself of certainty as its "very constitution rests on a concept of slippage

\footnotetext{
45 Ibid., p. I4.

${ }^{46}$ Ibid., p. 16.

47 Ibid., p. 22.

${ }^{48}$ Ibid., p. 16-I7.

49 Ibid., p. 5.
} 
away from a desperately solicited place." letter comes to be absent, exposing the decline in question. I fall upon it by inadvertence. This is often as one falls-while thinking elsewhere." ${ }^{\mathrm{II}} \mathrm{It}$ is in the "decline" of the slippage, or in the illustrative execution she makes by excluding the letter $m$, that the slippage as decline, allows Nathanaël to imbue the space leftover by the " $m$ " with an equivocal (multidirectional) signification. In other words, while in famille the language of filiation might be figured as a relation of descendants, the faille (fault line) she inserts into famille in order to re-place it (tectonically) with faille (au lieu) occasions a fortuitous mutation, a failure (défaillance) where descendant morphs into decline:

The faille might provide evidence of the defeat of the languages by which we might transmit ourselves, speak (of) ourselves, write (to) one another. Despite its emergence from the body that governs its movements, language nonetheless undertakes the conditioning of the body. The broken letter is also the breach that might provide for escape. The passage through. The break is the manifestation of that which I anticipate: if language determines me, I, too, can determine it. A defeat, the effect of which, far from being a reversal, is a re-placing, a distancing precisely of the familial, the familiara sort of linguistic free fall without markers-where I may resituate myself within a context I have yet to determine, but whose freedom depends precisely upon a previous confrontation, a fastening to a language, a word, a text, a single sense (rejecting sensuality, and therefore the body, desire), a determined interpretation. ${ }^{52}$

This is not the first instance of "defeat" in the text. Of relation, the first term Nathanaël uses to establish her narrative's itinerary in relation to Cahun, she maintains that "most of all [she] retain[s] defeat." 53 I should underline that in the aforementioned plea of defeat, I do not read a gesture of failure or impossibility, but rather a willingness to engage counter-steps, to deviate, to accept l'errance (mouvement + error). Another motive for associating defeat with de-feet (or from deviance to errance) is to re-signal the decline in question in the previously quoted passage, and therefore to suggest the downward movement (a downfall), a plunge or emptying into the abyss of the breach, which is described in one instance as a fall verging on madness. Why madness? Because in such re-placing and re-membering Nathanaël does not only fall, inadvertently, on Cahun's photograph—she falls into it:

\footnotetext{
so Ibid., p. 5-6.

5I Ibid., p. 22.

52 Ibid., p. 23

53 Ibid., p. 3.
} 
Some might take comfort in such proximity, a narrative from which to enlarge one's own. This is not at all my experience. On the contrary. I feel dread verging on madness [...] How can I put it? In her, I resemble myself. Not: I recognize myself. But resemble myself. There is no longer distinction, but indistinction. There is no longer differentiation, nor even difference, but absorption. Even more-or less-than this, there is subtraction, and not accretion as one might think, subtraction of one from the other, subtraction that results in the erasure, the nullification of the two of us [...] The photograph offers itself as an abyss. 54

While her relation with Cahun's photograph is described as abyssal, and while it does not quite garner a reading of elation like the kind produced between Moure and Pato, the caesura of the absent letter, though it requires disappearance and the emptying of the " $J E$," is also where, as the " $J E$ " breaks and frays, writing can emerge: "The photograph of Claude Cahun is, of course, not solely responsible for this degradation. The shock comes from its function as reminder, oddly making her into an ally, my companion on this path of extraction, of refusal, of emancipation, all of which [...] desired. What (s)he accuses (s)he proclaims. So much voluptuousness in this volatile field!"ss It is in the failure of reciprocity that the literary word flickers in the place of the exception, the remainder: where the absence-carried, emptied-gives way.

\section{By Way of a Very Brief CONCLUSION: CORRESPONDENCE/WHAT MOVES}

When, in the introduction, I quoted Bermann's inclination of the translator and to a kind of writing that is inclined, I was not yet considering that such inclinations might also have something to do with a writing/thinking on the move, one which I would later come to identify as a form of correspondence that had to do with the double movement of (re)reading and (re)writing. I found this link illustrated in the slippage embodied in the gap left open by the typographical figure " $\mathrm{m}$," and noted, in Nathanaël, how such a gap shares several resonances with the figure of the slash or the "with" slipped between Moure and Pato's work. Both the slash in Moure and Pato and the absent letter in Nathanaël (re)affirm the break or interruption nestled between the works-marking them as separate and yet (con)joined, coinciding, linked, coresponding, as letters on the move, the va et vient like echoes, the passage between languages as multiple and fractured-and translation, not as equivalence, but as

\footnotetext{
54 Ibid., p. 27-28.

55 Ibid., p. 59.
} 
inclination. In countering the uni-directionality (from source to target text) that is often employed to describe the movement of translation, I have attempted to show how translation is rather an encounter on both sides. Furthermore, in grounding my reading in a feminist theory of reading and the Canadian context of intercultural exchange that gave way to feminist experiments in translations, how translation, when slipped into the hands of the reader, is turned into a tridimensional object with neither a distinct here nor there, but a her: a subject who reads, who is marked by language, and who marks language also and her arrival there, to a place where inclination allows her, as translator, to be part of a pact, an act of exchange, a relationship text that is ongoing, incomplete, always on the make and ever on the move. 


\section{Letters On The Move: Erín Moure and Chus Pato's \\ Secession/Insecession and Nathanaël (Nathalie Stephens)'s Absence Where As (Claude Cahun and the Unopened Book)}

Geneviève Robichaud, Université DE Montréal

\section{RÉSUMÉ}

Dans ce texte, je me propose d'étudier l'espace d'échange et de dialogue déployé entre Secession-la traduction d'Erín Moure du galicien vers l'anglais d'un livre de la poète Chus Pato-et Insecession-le texte-écho que Moure signe en partie pour lui rendre hommage. Ces deux textes sont publiés au Canada dans une édition conjointe qui s'intitule Secession/Insecession (BookThug, 2014). Je fais en outre une lecture de Absence Where As (Claude Cabun and the Unopened Book) de Nathanaël (Nathalie Stephens), œuvre où l'auteure réfléchit sur sa relation vertigineuse à une photographie de Claude Cahun et au constat que, dans Cahun, elle se ressemble. Dans ces deux corpus, je m'intéresse à l'inclination d'un texte vers un autre et aux différentes possibilités d'échanges qu'une telle lecture peut offrir à la traduction. Alors que ces textes s'ouvrent à un jeu de correspondances plutôt qu'à une pratique d'équivalence, la traduction, à l'instar de ces exemples, devient un lieu privilégié pour une réflexion sur le va-et-vient des textes, leurs relations multiples et les réseaux d'inclination entre eux.

\section{ABSTRACT}

In this essay I examine the space for exchange and dialogue opened by Erín Moure's translation of Chus Pato's Secession, which in its Canadian edition is published alongside Insecession, Moure's own response or reciprocation to Pato's text. I also turn to Nathanaël's (Nathalie Stephens) relationship to a photograph of Claude Cahun and to the claim that in Cahun the author resembles herself. I argue that the eloquence of the inclination in both works, as each stages translation as a form of correspondence, suggests a failure of reciprocity and equivalences that denies the giving-over of one text to the other. Moure and Nathanaël thus underscore translation as a privileged site for reflecting on translation as a relationship text.

\section{NOTE BIOGRAPHIQUE}

Geneviève Robichaud is a PhD candidate in the Département de littératures et de langues du monde at the Université de Montréal. She is also a Board member of the Canadian Women in the Literary Arts (CWILA) and a member of the International Research Training Group (IRTG) on diversity. Her writing has appeared in The Capilano Review, Lemon Hound, The Puritan, and elsewhere. She is the author of Exit Text (Anstruther Press, 2016), a nano-essay on the errant and secret life of ideas. 